\title{
AGROTEKNIKA
}

\section{Pengaruh Pemberian Beberapa Dosis Pupuk Npk Terhadap Produksi Tanaman Melon di Rumah Kaca}

\section{The Influence Of Some Of NPK Fertilizer Dosage On Melon Production In Greenhouse}

\author{
Kuswandi*, Panca Jarot Santoso, Mega Andini, Nofiarli \\ Balai Penelitian Tanaman Buah Tropika, Solok, Sumatera Barat \\ *Penulis Korespondensi \\ Email: sutan.mangkuto33@gmail.com
}

\begin{abstract}
Abstrak. Budidaya melon di rumah kaca sangat rentan terhadap kekeringan dan kekurangan hara. Penelitian bertujuan untuk mengetahui pengaruh beberapa dosis NPK terhadap produksi melon di rumah kaca. Penelitian dilaksanakan di rumah kaca Balai Penelitian Tanaman Buah Tropika pada bulan April-Juni 2018. Materi yang digunakan pada penelitian ini adalah galur MB3, yang merupakan galur melon terpilih koleksi Balitbu Tropika. Percobaan disusun menurut uji $t$ berpasangan dengan 3 perlakuan dosis pupuk NPK, yaitu $100 \mathrm{~g}$ (control), $150 \mathrm{~g}$, dan $200 \mathrm{~g}$. Masing-masing perlakuan terdiri dari 30 tanaman, Peubah yang diamati terdiri dari bobot buah, lingkar buah, tebal daging buah, total padatan terlarut, panjang buah dan lebar buah. Hasil penelitian menunjukkan bahwa dosis pupuk NPK $100 \mathrm{~g}$ (kontrol) merupakan perlakuan terbaik, peningkatan dosis menyebabkan menurunnya kualitas buah.
\end{abstract}

Kata kunci: melon, NPK, pemupukan, produksi

Abstract. Melon cultivation in greenhouses is very vulnerable to drought and nutrient deficiencies. The study aims to determine the effect of several NPK doses on melon production in the greenhouse. The study was conducted in the greenhouse of the Indonesian Tropical Fruit Research Institute (ITFRI) in April-June 2018. The material used in this study was the MB3 strain, which is a melon strain selected from the ITFRI collection. The experiment was arranged according to paired t test with $3 \mathrm{NPK}$ fertilizer dosage treatments, namely $100 \mathrm{~g}$ (control), $150 \mathrm{~g}$, and $200 \mathrm{~g}$. Each treatment consisted of 30 plants. The observed variables consisted of fruit weight, fruit circumference, fruit flesh thickness, total solluble solids (TPT), fruit length and fruit width. The results showed that the dose of $100 \mathrm{~g} N P K$ fertilizer (control) was the best treatment, increasing the dose causing a decrease in fruit quality.

Keywords: melon, NPK, fertilization, production

\section{Pendahuluan}

Melon merupakan salah satu komoditas tanaman buah yang cukup diminati. Luas panen melon meningkat sebesar 0,94\% dari tahun 2013-2014. Luas panen melon pada tahun 2013 adalah seluas 7068 ha, sedangkan pada tahun 2014 seluas 8185 ha. Hasil panen melon pada tahun 2013 sebesar 125.207 ton dan pada tahun 2014 sebesar 150.347 ton (Kementerian Pertanian, 2018).

Budidaya melon di rumah kaca memiliki banyak keuntungan, di antaranya untuk meminimalkan serangan hama dan penyakit, terutama lalat buah yang merupakan hama utama 
pada tanaman melon. Bercocok tanam melon di rumah kaca juga menghalangi masuknya serangga pollinator, sehingga diperlukan penyerbukan buatan agar melon dapat berbuah (Tan et al., 2014).

Produksi tanaman melon di daerah beriklim kering maupun di rumah kaca sangat rentan terhadap kekeringan dan kekurangan hara. Pemupukan dengan dosis tinggi sangat diperlukan pada tanaman melon, karena tanaman ini memiliki siklus hidup yang sangat pendek. (Castellanos et al., 2011).

Pemupukan menggunakan pupuk NPK dapat meningkatkan panjang dan diameter batang, jumlah ruas, panjang ruas dan bobot kering biomasa pada tanaman labu (Sari et al. 2012). NPK juga berpengaruh terhadap komposisi kimia biji labu seperti kandungan protein, serat, abu, karbohidrat, dan lemak (Oloyede et al., 2012; Oloyede et al., 2013). Dosis yang banyak digunakan pada tanaman semusim seperti jagung, melon dan talas biasanya $200 \mathrm{~kg} / \mathrm{ha}$ NPK 15:15:15 (Ekwere \& Osodeke, 2013; Nmor, 2017). Pemberian pupuk NPK juga dapat meningkatkan produksi melon per satuan luas, dan meningkatkan persentase buah kelas A (Ginting \& Barus, 2017). Penelitian bertujuan untuk mengetahui pengaruh beberapa dosis pupuk NPK terhadap produksi melon di rumah kaca.

\section{Bahan dan Metode}

Bahan yang digunakan adalah melon galur MB3-1 hasil pemuliaan tim peneliti melon Balitbu Tropika, yang memiliki buah berbentuk bulat dengan warna kulit buah kuning gading dan TPT berkisar antara 14-17 ${ }^{\circ}$ brix. Penelitian dilaksanakan di rumah kaca Balai Penelitian Tanaman Buah Tropika pada bulan April-Juni 2018. Sebanyak 90 tanaman melon ditanam di dalam rumah kaca, setiap 30 tanaman diberi perlakuan pemupukan NPK (16-16-16) $100 \mathrm{~g}$ (kontrol), (16-16-16) $150 \mathrm{~g}$ dan (16-16-16) $200 \mathrm{~g}$.

Pupuk diberikan dengan cara dilarutkan di dalam 10 liter air kemudian diberikan sebanyak $220 \mathrm{ml} /$ tanaman. Dosis pupuk $100 \mathrm{~g}$ merupakan dosis yang biasa digunakan dalam budidaya melon di rumah kaca Balitbu Tropika. Pemupukan diberikan sejak tanaman berumur 10 hari, kemudian dilanjutkan seminggu sekali sampai 4 kali aplikasi. Ketika tanaman telah memasuki fase generatif, seluruh tanaman dipupuk dengan $100 \mathrm{~g}$ NPK (16-16-16) + $100 \mathrm{~g} \mathrm{KCl}$ yang dilarutkan di dalam 10 liter air. Pemupukan dilakukan sampai seminggu sebelum panen. Peubah yang diamati adalah bobot buah, lingkar buah, tebal daging buah, total padatan terlarut (TPT), panjang buah dan lebar buah.

Data dianalisa dengan uji t berpasangan menggunakan analysis toolpak pada Microsoft Excel. Pada analisa ini dibandingkan antara dua perlakuan, sehingga hipotesis yang digunakan adalah hipotesis dua arah dan dalam interpretasi data digunakan nilai t Critical two-tail sebagai nilai $\mathrm{t}$ tabel. Jika nilai $\mathrm{t}$ hitung $(\mathrm{t}$ stat) $>\mathrm{t}$ tabel maka $\mathrm{H} 0$ ditolak, dan terdapat perbedaan yang 
signifikan antara perlakuan 1 dengan perlakuan 2. Uji hipotesis juga dapat dilakukan dengan membandingkan nilai $\mathrm{P}(\mathrm{T}<=\mathrm{t})$ two-tail dengan $\alpha 5 \%$. Jika $\mathrm{P}(\mathrm{T}<=\mathrm{t})$ two-tail $<\alpha 5 \%$, maka $\mathrm{H} 0$ ditolak.

\section{Hasil dan Pembahasan}

Hasil analisis uji t menunjukkan bahwa pemberian pupuk NPK $150 \mathrm{~g}$ berpengaruh nyata terhadap kontrol pada peubah bobot buah, lingkar buah, tebal daging, TPT, dan panjang buah. Hasil analisis uji $t$ dapat dilihat pada Tabel 1.

Tabel 1. Rata-rata bobot buah, lingkar buah, tebal daging, TPT, panjang buah dan lebar buah pada dosis pemberian pupuk NPK 100 dan $150 \mathrm{~g}$.

\begin{tabular}{lrr}
\hline \multicolumn{1}{c}{ Peubah } & \multicolumn{1}{c}{ A } & \multicolumn{1}{c}{ B } \\
$(100 \mathrm{~g} \mathrm{NPK})$ & $(150 \mathrm{~g} \mathrm{NPK})$ \\
\hline Bobot buah $(\mathrm{g})$ & $1.25^{*}$ & $1.02^{*}$ \\
Lingkar buah $(\mathrm{cm})$ & $42.44^{*}$ & $39.22^{*}$ \\
Tebal daging $(\mathrm{cm})$ & $3.7^{*}$ & $3.56^{*}$ \\
TPT $\left({ }^{\circ}\right.$ brix $)$ & $14.97^{*}$ & $14.78^{*}$ \\
Panjang buah $(\mathrm{cm})$ & $12.73^{*}$ & $11.95^{*}$ \\
Lebar buah $(\mathrm{cm})$ & $13.42^{*}$ & $12.31^{*}$ \\
\hline
\end{tabular}

*) berbeda nyata dengan uji t berpasangan pada taraf $5 \%$

Tabel 1 memperlihatkan bahwa rata-rata bobot buah tertinggi terdapat pada perlakuan kontrol, yaitu 1,25 kg, sedangkan rata-rata bobot buah pada dosis $150 \mathrm{~g}$ hanya 1,02 kg per buah. Sejalan dengan tingginya bobot buah pada perlakuan kontrol, peubah lainnya yang meliputi lingkar buah, tebal daging, TPT, panjang buah, dan lebar buah, lebih tinggi daripada perlakuan B. Lingkar buah pada kontrol adalah sebesdar 42,44 cm, sedangkan pada perlakuan B hanya 39,22 $\mathrm{cm}$. Begitu juga pada peubah tebal daging buah, rata-rata tebal daging buah pada tanaman kontrol adalah 3,7 cm, sedangkan perlakuan B hanya $3,56 \mathrm{~cm}$. Nilai total padatan terlarut yang biasanya mengindikasikan tingkat kemanisan, perlakuan A memberikan nilai TPT yang lebih tinggi dan signifikan terhadap perlakuan B. Tingkat kemanisan daging buah pada perlakuan A adalah 14, 97 $\circ$ brix, sedangkan pada perlakuan B hanya $14,78^{\circ}$ brix.

Hasil analisa uji t dalam membandingkan antara pemberian pupuk NPK $100 \mathrm{~g}$ dengan pemberian pupuk NPK 200 g juga menunjukkan pengaruh yang signifikan dapat dilihat pada Tabel 2. Peubah rata-rata bobot buah, lingkar buah, tebal daging buah, panjang buah, dan lebar buah menunjukkan pengaruh yang signifikan antara perlakuan A dan perlakuan C. Pengaruh yang tidak signifikan terlihat pada peubah total padatan terlarut.

Tabel 2. Rata-rata bobot buah, lingkar buah, tebal daging, TPT, panjang buah dan lebar buah pada dosis pemberian pupuk NPK 100 dan $200 \mathrm{~g}$

\begin{tabular}{lrr}
\hline \multicolumn{1}{c}{ Peubah } & A & \multicolumn{2}{c}{$\mathrm{C}$} \\
& $(100 \mathrm{~g} \mathrm{NPK})$ & $(200 \mathrm{~g} \mathrm{NPK})$ \\
\hline Bobot buah $(\mathrm{g})$ & $1.25^{*}$ & $0.8^{*}$ \\
Lingkar buah $(\mathrm{cm})$ & $42.44^{*}$ & $36.36^{*}$ \\
Tebal daging $(\mathrm{cm})$ & $3.7^{*}$ & $2.93^{*}$
\end{tabular}




\begin{tabular}{lrr}
\cline { 2 - 2 } Total padatan terlarut $\left({ }^{\circ}\right.$ brix $)$ & 14.97 & 14.92 \\
Panjang buah $(\mathrm{cm})$ & $12.73^{*}$ & $10.98^{*}$ \\
Lebar buah $(\mathrm{cm})$ & $13.42^{*}$ & $11.43^{*}$ \\
\hline
\end{tabular}

*) berbeda nyata dengan uji t berpasangan pada taraf 5\%

Rata-rata bobot buah pada perlakuan A (kontrol) lebih besar daripada perlakuan $\mathrm{C} \mathrm{g}$, yaitu 1,25 kg per buah pada kontrol, dan 0,8 kg per buah pada perlakuan C. Begitu juga dengan semua peubah lainnya menunjukkan bahwa perlakuan A memiliki rata-rata yang lebih besar dibandingkan perlakuan $\mathrm{C}$.

Rendahnya rata-rata semua peubah pada perlakuan pupuk NPK sebenarnya bukanlah merupakan fenomena yang unik. Beberapa petani melon menjelaskan bahwa melon merupakan tanaman yang tidak rakus dalam memanfaatkan hara. Beberapa hasil penelitian juga menunjukkan bahwa penggunaan pupuk NPK dengan dosis yang berlebih dapat membahayakan bagi tanaman dan merusak tanah (Popoola et al., 2015; Sun et al., 2019).

\section{Kesimpulan}

Dosis pemupukan NPK terbaik pada galur melon MB3-1 adalah $100 \mathrm{~g}$ yang dilarutkan di dalam 10 liter air dan diberikan sebanyak $220 \mathrm{ml}$. Peningkatan dosis menyebabkan penurunan kualitas buah, seperti bobot buah, lingkar buah, panjang buah, lebar buah dan tebal daging buah

\section{Daftar Pustaka}

Castellanos, M. T., Cabello, M. J., Cartagena, C., María, A., Arce, A. \& Ribas, F. (2011). Growth Dynamics and Yield of Melon as Influenced by Nitrogen Fertilizer Dinâmica Do Crescimento e da Produtividade do Melão em Resposta ao Fertilizante Nitrogenado. Sci. Agric. (Piracicaba, Braz.). 68 (2), 191-199.

Ginting, A.P., \& Barus, A. S. (2017). Pertumbuhan dan Produksi Melon (Cucumis meloL.) terhadap Pemberian Pupuk NPK dan Pemangkasan Buah. Jurnal Agroekoteknologi FPUSU. 5 (4), 786-798.

Nmor, E. I., \& Okobia, U. B. (2017). Effect of Different Levels of N.P.K. 15 : 15 : 15 Fertilizer Application on the Yield of Sweet Potato (Ipomea Batatas) in South-South Nigeria. International Journal of Environment, Agriculture and Biotechnology (IJEAB). 2 (5), 23362339.

O J Ekwere C O \& Osodeke, MJEVE. (2013). Growth and Yield Parameters of Maize and Egusi Melon in Intercrop as Influenced by the Cropping System and Different Rates of NPK Fertilizer. The Scientific World Journal. 1, no. November, 69-75.

Oloyede, F. M., Agbaje, G. O. \& Obisesan, I. O. (2013). Analysis of Pumpkin (Cucurbita pepo Linn.) Biomass Yield and Its Components as Affected by Nitrogen, Phosphorus and Potassium (NPK) Fertilizer Rates. African Journal of Agricultural Research. 8 (37), 46864692.

Oloyede, F. M., Obisesan, I. O., Agbaje, G. O. \& Obuotor, E. M. (2012). Effect of NPK Fertilizer on Chemical Composition of Pumpkin (Cucurbita pepo Linn.) Seeds. The Scientific World Journal. 2012, 1-6.

Pertanian, K 2018, Statistik Pertanian 2018 SAA\& B Waryanto (ed), Jakarta. 
Popoola, O. P., Adesanya, K. K., Odusina, T. M. \& Ayanrinde, A. W. (2015). A Quadratic Regression Analysis of the Effect of Three Levels of NPK Fertilizer on the Yield of Yellow Maize. American Journal of Computational Mathematics. 5, 426-430.

Sari, S, Rosmawaty, T \& Gultom, H. (2012). Uji Penggunaan Ethrel dan Pupuk NPK Terhadap Produksi Melon (Cucumis Melo. L). Dinamika Pertanian. 27 (3), 141-148.

Sun, Y, Hu, R \& Zhang, C. (2019). Does the Adoption of Complex Fertilizers Contribute To Fertilizer Overuse? Evidence From Rice Production in China. Journal of Cleaner Production. 219 (3), 677-685.

Tan, S. P., Parks, S. E., Stathopoulos, E. \& Roach, P. D. (2014). Greenhouse-Grown Bitter Melon : Production and Quality Characteristics. J Sci Food Agric. 94 (9), 1896-1903. 